3. Термін «контекстуальний переклад» зазвичай протиставляють «словниковому перекладу», таким чином вказуючи на відповідності, яке слово може мати в контексті на відміну від вказаних в словнику.

Вибір конкретного прийому при перекладі залежить напряму від задачі, яка стоїть перед перекладачем: зберегти колорит мовної одиниці із можливими втратами для семантики або передати значення реалії, загубивши при цьому колорит. Успішне виконання функцій перекладача передбачає всебічне знайомство 3 історією, культурою, літературою, звичаями, сучасним життям та іншими реаліями народу, що говорить мовою оригіналу. Іншими словами, основною вимог до повноцінного перекладу є знання перекладачем реалій або конкретних умов життя i побуту країни, з мови якої здійснюється переклад.

\title{
Література:
}

1. Томахин Г. Д. Реалии-американизмы : пособие по страноведению. Москва : Высшая школа, 1988. 239 с.

2. Зорівчак Р. П. Реалія і переклад : монографія. Лівів : Видавництво Львівського університету, 1989. $216 \mathrm{c.}$

3. Влахов С., Флорин С. Непереводимое в переводе. Москва : Р. Валент, 2006. 448 с.

4. Швейцер А. Д. Перевод и лингвистика. Москва : Воениздат, 1973. 280 c.

DOI https://doi.org/10.30525/978-9934-26-039-1-74

\section{ТРОПИ У КАЗЦІ О. ПРОЙСЛЕРА «МАЛЕНЬКА БАБА ЯГА» ТА ЇХ ПЕРЕКЛАД}

\author{
Кучма Т. В. \\ кандидат філологічних наук, \\ дочент кафедри романо-германської філології \\ Рівненського державного гуманітарного університету \\ м. Рівне, Украӥна
}

Мова художньої літератури відрізняється від інших стилів не тільки за складом мовних засобів, але й своїми художньо-естетичними якостями. Це образна мова, що має в своєму розпорядженні історично вироблену систему засобів словесно-художньої зображувальності $[3$, c. 60$]$. 
Оскільки мовні одиниці в художньому тексті виконують подвійну функцію - комунікативну та естетичну, - слово у ньому, як зазначає T. Крайнікова [2, с. 10], може реалізовувати не тільки свої безпосередні номінативні значення, але й художньо-стилістичні, зі всіма притаманними їм емоційними, експресивно-образними компонентами.

Творче, яскраво індивідуальне використання мовних засобів - одна 3 основних особливостей художньої мови, яка й визначає ії своєрідність серед інших стилів. Індивідуально-художній стиль письменника становить систему мовних засобів, що сформувалася в результаті відбору i творчого використання лексичних і синтаксичних явищ національної мови не тільки для вираження певного змісту, але й для естетичного впливу на читача.

На думку науковців [3, с. 14], образність мови - це також категорія мовностилістична, оскільки ця якість утворюється за допомогою значеннєвої своєрідності слів, а також прийомів використання, способів розташування різноманітних мовних засобів. Мова стає образною тоді, коли в словах активізуються метафоричні значення та інші змістовні нашарування, коли використовуються порівняння, перифрази та ін. в таких випадках слова позначають поняття та речі i визивають в свідомості яскраві картини та асоціації

Виражальним засобам мови, що забезпечують виразність і образність мовлення, присвячені праці Г. Апресяна, Н. Бабич, М. Ільяша, В. Ковальова, М. Кожиної, М. Пентилюк, О. Пономаріва, Л. Лужецької, Т. Крайнікової, Н. Дзюбишиної-Мельник та інших. Однак мова творів популярного дитячого письменника Отфріда Пройслера ще не була предметом наукових розвідок.

Джерельною базою дослідження $€$ текст казки німецького письменника Отфріда Пройслера «Мала Баба Яга» (О. Preußler «Die Kleine Hехе») та його переклад українською мовою, здійснений В. Василюком.

За визначенням «Словника лінгвістичних термінів» [1, с. 313], троп - це мовний зворот, у якому слово або словосполучення вжиті в переносному значенні і служать засобом досягнення естетичного ефекту виразності в мові художньої літератури, в публіцистиці, в ораторському стилі тощо. До тропів зазвичай відносять епітет, порівняння, метафору, метонімію, синекдоху, гіперболу, літоту, оксиморон, іронію, уособлення тощо.

Проаналізуємо тропи, використані у тексті казки О. Preußler «Die Kleine Нехе», та їх переклади, здійснені В. Василюком.

Порівняння - зіставлення одного предмета 3 іншими на основі їх спільної ознаки; своєрідний живопис словом, спрямований на те, щоб розбудити уяву слухача (читача): 
Wenn mich Abraxas jetzt sehen könnte, würde er Augen machen wie eine Waldeule! [5] - Якби мене оце побачив Абраксас! Витріщив би з подиву очі, як сова! [4, с. 9].

У системі засобів поетичного увиразнення мовлення порівняння виступає, чи, точніше, психологічно сприймається як форма ускладнення епітета, свого роду розгорнутий епітет.

Епітет - це слово, що вказує на одну з ознак того предмета, який називається, і має на меті конкретизувати уявлення про нього. Епітет інакше ще називають образним або поетичним означенням, підкреслюючи в такий спосіб його протиставленість логічному означенню предмета, завдання якого також полягає в тому, щоб конкретизувати уявлення про предмет, про який ідеться:

Die kleine Hexe lachte in sich hinein, denn ihr war bei den Worten des Raben ein lustiger Einfall gekommen [5] - Мала Баба Яга стиха засміялась після воронових слів їй сяйнула весела думка $[4$, с. 50].

Метафорою називається слово, значення якого переноситься на найменування іншого предмета, пов'язаного 3 предметом, на який звичайно вказує це слово, рисами подібності:

Die Sonne hatte dem Winter Beine geтасht [5] - Сонце проганяло зиму далі й далі [4, с. 53].

Метонімія - це слово, значення якого переноситься на найменування іншого предмета, пов'язаного з властивим для даного слова предметом за своєю природою:

Vorneweg zog die Schützenkapelle und blies einen lustigen Marsch nach dem anderen [5] - Попереду всіх ішов оркестр, виграючи один за одним веселі марші [4, с. 42].

Гіпербола - стилістична фігура явного і навмисного перебільшення для посилення виразності і підкреслення сказаної думки:

Auf dies hin bestürmte der Rabe Abraxas die kleine Hexe mit tausend Fragen [5] - У ворона Абраксаса відразу виникло тисячу запитань до малої Баби Яги [4, с. 50].

Оксиморон - літературно-поетичний прийом, котрий полягає у поєднанні протилежних за змістом, контрастних понять, що спільно дають нове уявлення:

Der kleinen Hexe genügte es aber, sie hätte sich gar kein schöneres Hexenhaus wünschen können. Es hatte ein wundervoll windschiefes Dach, einen krummen Schornstein und klapprige Fensterläden [5] - А вже кращої оселі вона й побажати собі не могла. Дах на хатичі дуже гарно скособочився од вітру, димар похилився, а віконниці раз у раз скрипіли [4, с. 6].

Іронія - засіб художньої виразності, прихована насмішка, коли за зовні позитивним висловлюванням ховається висміювання: 
«Buttermilch!» kreischte Abraxas. «Mir scheint, du bist vollständig übergeschnappt! Was willst du denn noch alles regnen lassen? Wäscheklammern vielleicht? Oder Schustemägel? Wenn es doch wenigstens Brotkrümel oder Rosinen wären!» [5] - Кисляк! - вигукнув Абраксас. - Ти 3 глузду з'їхала! Що ти нам іще начаклуєш? Може, прищепок для білизни? Чи шевських гвіздків? Хоч би вже там з неба сипалися крихти хліба чи родзинки! [4, с. 7].

Отже, у казці О. Пройслер використовує практично всі тропи: епітет, порівняння, метафору, метонімію, гіперболу, оксиморон, іронію. У літературно-художньому перекладі В. Василюку вдалося відтворити не тільки зміст і форму першотвору, а й передати авторський задум, характери персонажів, авторський стиль, художні засоби і стилістичні фігури твору мови-оригіналу.

\title{
Література:
}

1. Ганич Д. І., Олійник І. С. Словник лінгвістичних термінів. Київ : Вища школа, 1985. 360 с.

2. Крайнікова Т. Мова художнього твору. Київ : Дніпро, 2002. 150 с.

3. Плющ М. Я., Бевзенко С. П., Грипас Н. Я. Сучасна українська літературна мова: Підручник. Київ : Вища школа, 2003. 430 с.

4. Пройслер О. Мала Баба Яга. Водяничок / Перекл. 3 нім. і передм. В. Т. Василюка. Київ : Веселка, 1992. С. 5-68.

5. Preußler O. Die Kleine Hexe. URL: https://www.rulit.me/books/diekleine-hexe-download-304608.html

DOI https://doi.org/10.30525/978-9934-26-039-1-75

\section{СПОСОБИ ПЕРЕКЛАДУ РЕАЛІЙ У РОМАНІ ДЖЕЙН ОСТІН «НОРТЕНГЕРСЬКЕ АБАТСТВО»}

\author{
Нікіфорова Т. В. \\ магістрантка спеиіальності «Філологія» \\ Івано-Франківського національного технічного університету \\ нафти і газу \\ м. Івано-Франківськ, Украӥна
}

Слова-реалії - це своєрідні коди, які відображають національні особливості певного народу. Оскільки зараз ми спостерігаємо процес злиття культур, то дуже важливо звертати увагу на культурно марковану лексику. Такі слова допомагають читачеві відчути характерні риси 